
Kyiv-Mohyla Counter-Reformation

Author: Ihor Isichenko

Source: Kyiv-Mohyla Humanities Journal 2 (2015): 65-82

Published by: National University of Kyiv-Mohyla Academy

http://kmhj.ukma.edu.ua/ 


\title{
Sylvester Kosov's Exegesis (1635): A Manifesto of the Kyiv-Mohyla Counter-Reformation?
}

\author{
Ihor Isichenko, Archbishop \\ V. N. Karazin Kharkiv National University, \\ Department of History of Ukrainian Literature
}

\begin{abstract}
Bishop Sylvester Kosov's polemical treatise The Exegesis (1635) is regarded as evidence of new trends in Kyiv theology, reflecting the entry of Orthodox thinkers of the Polish-Lithuanian Commonwealth (Rzeczpospolita) into the spiritual sphere of European Reform, traditionally defined as the Counter-Reformation. The treatise's author, being the closest associate of Metropolitan Petro Mohyla, denies the Byzantine theologians' accusations of pliancy to Protestant influences. Demonstrating doctrinal differences with Calvinism, Lutheranism, and Unitarianism, Sylvester Kosov determines his own faith identity and its natural connection to the apostolic tradition and the teachings of the Church Fathers. In doing so, he uses expressive Baroque imagery.
\end{abstract}

Key words: Sylvester Kosov, Petro Mohyla, Counter-Reformation, polemical literature, Church Fathers, Baroque.

\section{(7)}

\section{Traces of Old Conflicts}

Sylvester Kosov's small book Exegesis to iest danie sprawy o szkotach kiowskich y winnickich (1635) remains a minor episode in the literary life of Mohylanian Kyiv. Published simultaneously with the Polish edition of The Kyivan Cave Patericon (Patericon abo Żywoty śs. Ojców Pieczarskich), it naturally yielded to the latter in popularity. And despite Sylvester Kosov's authority, that of the closest associate of Petro Mohyla and his successor at the Kyiv Metropolitan Cathedra, ${ }^{1}$ saved the book from complete oblivion. Researchers referred to it only occasionally, limiting their narratives to rendering or quoting the vivid memoirs of conservative Kyivans' hostile attitudes towards the Latin-speaking Kyiv Cave (Lavra) School2: "Był ten czas, żechmy się

Antoni Mironowicz, Sylwester Kossow — biskup białoruski, metropilita kijowski (Białystok: Białoruskie Towarzystwo Historyczne, 1999).

2 In particular see: S. T. Golubev, vol. 1 of Kievskii mitropolit Petr Mohyla i ego spodvizhniki (Opyt istoricheskogo issledovaniia): $v 2$ t. [Metropolitan of Kyiv Petro Mohyla and his Associates: Experience of Historical Research, 2 vols.] (Kyiv: Typ. H. T. Korchak-Novytskogo, 1883), 12; Z. I. Khyzhniak, KievoMohylianskaia akademiia [Kyiv-Mohyla Academy] (Kyiv: Vyshcha shkola, 1988), 56; I. Isichenko, Kyievo-Pecherskyi pateryk u literaturnomu protsesi kintsia XVI — pochatku XVIII st. na Ukraini 
wyspowiadawszy, tylko ióż oczekiwali, póki nami xięńce dnieprowych iesiotrów nadziewać zechcą, abo póki iednego ogniem, drugiego mieczem na drugi swiat zasłą" ["It was a time when after confession we just feared that we would be fed to Dnieper sturgeons, or when one by fire, and the other by sword would be sent to the other world"]..$^{3}$ A sole special study appeared in Canada in $1958^{4}$ and, quite naturally, remained unknown in Ukraine. It was only in 2014 that Natalia Sinkevych included more detailed information on the Exegesis in her monograph on Sylvester Kosov's Paterikon. ${ }^{5}$

Undoubtedly, it is important to acknowledge the emotional dimension of conflicts associated with the difficult reaction of supporters of Byzantine-Slavic exclusivism to the innovative nature of the school founded at the Kyiv Cave Monastery in September 1631 by Archimandrite Petro Mohyla in order to understand the inertia which the reformer's daring plans had to face. However, it was a forgotten episode for the author of the Exegesis. The Kyiv Cave and Brotherhood schools had already been united, and the former Kyiv Cave Prefect held the same position at the Kyiv-Mohyla Collegium, where Latin naturally prevailed. Sylvester Kosov recalled the old conflicts with irony, ascertaining the fact that the lower middle class citizens of Kyiv had started to populate the new school with their children, like a formicary. Enjoying the recognition, he advantageously compared the school to Helicon and Parnassus,

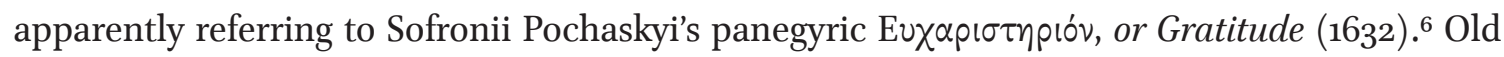
problems and collisions had passed away.

Instead, the author's utter focus on the criticism of Protestant theological doctrines and demonstration of irreconcilable contradictions between Orthodox theology and the doctrines of Arians, Calvinists, and Lutherans was new for Ukrainian polemical prose. There are practically no motifs that are traditional for native polemicists and related to the demonstration of Byzantine identity in contrast to the Latin rite and western theological teaching. Moreover, Sylvester Kosov extensively utilized Latin theological terminology, texts of the Vulgate, and patristic writings, authoritative in Catholic circles.

Thus, a new trend can be traced, fundamentally different from the predominant disposition of the early polemic prose produced at Ostroh Academy and the Lviv and Vilnus (Wilno) Brotherhood schools. ${ }^{7}$ It is worth remembering the forced union of dissidents, both Orthodox

[Kyiv-Pechersk Patericon in the Literary Process of the Late 16th - Early 18th Century in Ukraine] (Kyiv: Naukova dumka, 1990), 6o.

3 Sylwestr Kossow, "Exegesis, to iest danie sprawy o szkołach kiowskich y winnickich (1635)," Arkhiv Iugo-Zapadnoi Rossii 8.1 (1914): 423. Further references to this edition of the text.

4 Iurii Gerych, “Exegesis Sylvestra Kossova," ["Exegesis by Sylvester Kossov,”] (Yorkton, 1958).

5 Nataliia Sinkevych, "Paterykon" Sylvestra Kosova: Pereklad ta doslidzhennia pamiatky [Sylvester Kosov's Paterykon: Translation and Research of the Document] (Kyiv: Oleh Filiuk Publ., 2014), 109-10.

6 V. I. Krekoten and M. M. Sulyma, comp., Ukrainska poeziia: Seredyna XVII st. [Ukrainian Poetry: Mid-17th Century] (Kyiv: Naukova dumka, 1992), 174-88.

7 Vitalii Shevchenko, Pravoslavno-katolytska polemika ta problemy uniinostiv zhytti Rusy-Ukrainy doberesteiskoho periodu: Monohrafiia [Orthodox-Catholic Polemics and Problems of Union in Life of Rus-Ukraine of the Pre-Brest Period: A Monograph] (Kyiv: Presa Ukrainy, 2002), 197-212. 
and Protestant, who defended their rights in the Lithuanian Commonwealth by means of a Sejm struggle and even managed to conclude the Confederation Act in $1599 .{ }^{8}$ This political context significantly influenced the system of priorities in literary polemics.

Then the situation changed. The Ostroh Academy declined; in the times of Petro Konashevych Sahaidachnyi the Cossacks' noble ambitions determined a new class doctrine with a powerful church component. ${ }^{9}$ In Kyiv, the Epiphany Brotherhood and the printing house of the Kyiv Caves Monastery becomes the centre of an intellectual circle whose spiritual guidance naturally depended on the local tradition, reliance on the medieval cult of relics, and the mythologized remembrance of the princely era. Finally, the return of Kyiv's role as the metropolitan centre of the Rus' Church in 1620 and the conflict with the royal administration stimulated the national elite's careful search for a political alternative to the Polish-Lithuanian Commonwealth.

At the same time, Ukrainian realities entered the general context of civilizational changes in Central and Eastern Europe, integrated by the concept of the Counter-Reformation. A tolerant image of the "heretics' shelter" 10 gradually retreated to the past.

Attributed to Zechariah Kopystensky, the Book of the Only Faith (Knyha o viri iedynoi, 1619), ," was an important attempt at self-identification for the Orthodox community of the Polish-Lithuanian Commonwealth. Yet for separate tendencies to form a larger picture, the Kyiv Metropolis needed the systematic changes associated with Petro Mohyla, ${ }^{12}$ which would be consonant with the post-Trent transformations of the Western Church.13 Under these circumstances, the appearance of the Exegesis treatise (1635) was particularly symptomatic. By using the concepts of Trent Theology, the author actually confuted the allegations of the influence of Reformation ideas on the Orthodox consciousness. Demonstrating allegiance of the Orthodox schools in Kyiv and Vinnytsia to the patristic tradition, Sylvester Kosov mediated addressing this tradition with its contemporary reception in European theology; at the same time, the Orthodox segment in university theology remained quite narrow and was mainly fuelled by the new ideas of Roman Catholic doctrine.

Another factor remained a burning question for Petro Mohyla's circle. After Meletiusz Smotrytskyi's unsuccessful trip to the Greek East and the break between the Archbishop

8 Ivan Vlasovskyi, vol. 2 of Narys istorii Ukrainskoi Pravoslavnoi Tserkvy [An Outline of the History of the Ukrainian Orthodox Church] (New York; Kyiv; Bound Brook, 1990), 8-10.

9 Serhii Plokhii, Nalyvaikova vira: Kozatstvo ta relihiia v ranniomodernii Ukraini [Nalyvayko's Faith: Cossacks and Religion in Early Modern Ukraine], trans. Sofiia Hrachova (Kyiv: Krytyka, 2005), 145-63. Janusz Tazbir, "Tolerancja w dawnej Polsce," in Chrześciaństwo w dialogu kultur na ziemiach Rzeczypospolitej (Lublin:Wyd-wo KUL, 2003), 55.

11 Iu. V. Larin "Kniga o vere iedinoi' (1619 r.) v konteksti rannioi barokovoi polemichnoi literatury” ["The Book of the Only Faith (1619) in the Context of the Early Baroque Polemical Literature"] (PhD diss. 10. o1. o1, Kharkiv, 2013).

12 Arkadii Zhukovskyi, Petro Mohyla i pytannia iednosty Tserkov [Petro Mohyla and the Question of Unity of Churches] (Kyiv: Mystetstvo, 1997), 77-108.

13 Diarmaid MacCulloch, $A$ History of Christianity: The First Three Thousand Years (London: Penguin Books, 2010), 667-715. 
Meletiusz and Kyiv's Orthodox hierarchy, ${ }^{14}$ works appeared in which he criticised the current state of Byzantine theology and accused the writers with deviation from Christian Orthodoxy:

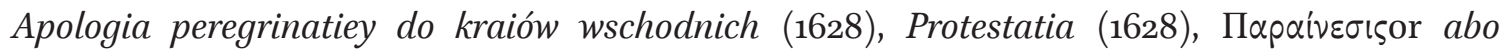
Napomnienie (1629), Exethesis abo Expostulatio, to iest Rozprawa między Apologia z Antidotem o ostanek btędów, hereziy y klamstw Zyzaniowych, Philaletowych, Orthologowych y Klerykowych uczyniona (1629). "Rus Theologists" Stephan Zyzani, Christophor Philaret, Cleric of Ostroh, Wasyl Surazski, Zacharia Kopystenskyi ("Azaria") and the early Meletiusz Smotrytskyi as the author of Threnos, hidden under the pseudonym of Teofil Ortholog, are treated in the Apology as "zwodcy nasze z prawdziwey wiary" ["those who lead us off the true faith"]. ${ }^{15}$

Publication of Patriarch Cyril Lucaris' of Constantinople Confession in Geneva in 1629 was a significant argument in support of these charges, ${ }^{16}$ in which significant concessions to Calvinism were found: the contraposition of baptism and the Eucharist to other sacraments, questionable judgments of the consecration of bread and wine into the Body and Blood of Christ, lack of references to the Holy Tradition, Ecumenical Councils (Synods) and the work of the Church Fathers, a critical attitude to the cult of icons, and allegations of salvation through faith in Christ. ${ }^{17}$ The scandal around The Confession of Cyril Lucaris nourished suspicions spread by Meletiusz Smotrytskyi concerning the loss of the purity of faith and dependence on the Protestant doctrines by contemporary Orthodox theologians.

\section{Criticism of Protestants}

Sylvester Kosov successively analyses the three main "other-faith" doctrines, comparing them to Orthodox teaching, but he focuses on refuting allegations about the influence of Calvinism on Byzantine ecclesiological views. Two main aspects are highlighted: sacramental (the teaching of church sacraments) and soteriologic (the doctrine of salvation). Contrary to Calvin's views of the sacraments, defined as "prozwierzchowny znakie, którem obietnica łaski iest przyłączona" ("signs from above, which are associated with the promise of grace"), 18 the author shares a post-Trent interpretation: "sacrament iest znakiem y przyczyną łaski, a znakami od Boga

14 Meletii Solovii, ChSVV, part 1 of Meletii Smotrytskyi iak pysmennyk [Meletiusz Smotrzyskyi as a Writer] (Rome; Toronto: Pp. Basiliani, 1977), 193-225; Petro Kraliuk, Meletii Smotrytskyi i ukrainske dukhovnokulturne vidrodzhennia kintsia XVI — pochatku XVII st. [Meletiusz Smotrzyski and Ukrainian Spiritual and Cultural Revival of the Late 16th — Early 17th Centuries] (Ostroh: Vyd-vo Natsionalnoho universtytetu “Ostrozka akademiia," 2007), 134-50.

15 Meletiusz Smotrzyski, Apologia peregrinatiey do kraiow wschodnich (Lwów, 1628).

16 "The Confession of Cyril Lucaris (Eastern Orthodox, 1629)," in Christian Resource Institute, accessed February 26, 2015, http://www.crivoice.org/creedcyril.fhtml.

17 Steven Runciman, Velikaia Tserkov v plenenii: Istoriia Hrecheskoi tserkvi ot padeniia Konstantinopolia v 1453 g. do 1821 g. [Great Church in Captivity: The History of the Greek Church from the Fall of Constantinople in 1453 to 1821], trans. L. A. Gerd (Saint Petersburg: Izd-vo Olega Abyshko, 2006), $282-87$.

18 Kossow, "Exegesis," 426-27. 
postanowionymi" ["the sacrament is a sign and the reason of the grace of God"]..$^{19}$ This can be compared to popular Robert Bellarmin's Catechism's definition: "znak widomy łaski Bożey niewidomey na poświęcenie człowieka od Chrystusa Pana postanowiony" ["a visible sign of the invisible grace of the Lord Jesus Christ, given for consecrating man"]. ${ }^{20}$ Thus, the emphasis is placed on God establishing the sacrament, the apparent character (matter) of the sacrament and - most importantly — on the direct bearing of God's grace on the sacrament. Further, Sylvester Kosov rejects Calvin's narrowing the number of sacraments to three (baptism, the Lord's Supper, and ordination, or Consecration) and asserts: "My zaś, według tradycyey Cerkwie Wschodniey, matki naszey, sacramentów mamy siedm" ["According to the tradition of our mother, the Eastern Church, we have seven sacraments"]. ${ }^{21}$ It is appropriate to mention that in Chapter 15 of Cyril Lucaris' Confession the number of sacraments was reduced not to three, like in Calvin's, but to two: "We believe that Evangelical Sacraments, established by God in the Gospels, are in the Church and they are two. We do not have more Sacraments, because He, Who established them, did not leave more with us." ${ }^{22}$ The Council of Trent firmly and peremptorily specified: "If anyone said that not all sacraments of the New Rule were established by Jesus Christ, our Lord, or there were more or fewer of them than seven, namely Baptism, Confirmation, the Eucharist, penance, anointing of the sick, consecration, and marriage; or that some of those seven were not true and separate sacraments - may he be execrated." ${ }^{23}$

Although the author refers to patristic sources and "the traditions of the Eastern Church," the doctrine of the seven sacraments was shaped in the Latin West and was finally consolidated by the Council of Trent in the decrees on the sacraments. ${ }^{24}$ Despite adoption of this teaching by the Byzantine East, ${ }^{25}$ a mildly critical approach to the codification of the sacraments, far from the peremptory message of the Eastern Patriarchs of 1723, predominates in Orthodox theological literature. ${ }^{26}$

In Sylvester Kosov's interpretation of certain sacraments one can consistently observe the influence of Western Sacramentology and its teaching of the matter and form of the sacraments.

19 Margarita Korzo, Ukrainskaia i belorusskaia katekheticheskaia traditsiia kontsa XVI - XVIII vv.: Stanovlenie, evoliutsiia i problema zaimstvovanii [Ukrainian and Belarusian Catechetical Tradition of the End of the 16th-18th Centuries: Establishment, Evolution and the Problem of Borrowings] (Moscow: Kanon+, 2007), 19-103. Robert Bellarmin, Katechizm rzymski abo krotka nauka katolicka wszystkim chrześcianom do zbawienia naypotrzebniejsza (Wilno, 1752), 51.

21 Kossow, "Exegesis," 427.

22 "Confession of Cyril Lucaris."

23 Vol. 4 (1511-1870) of Dokumenty Soborów Powszechnych: Tekst taciński, polski (Kraków: WAM, 2005), 356.

24 Dokumenty Soborów, 356-64; 444-58; 482-512; 714-32.

25 Pravoslavna vira Iedynoi, Sviatoi, Sobornoi i Apostolskoi Tserkvy: Poslannia Skhidnikh Patriiarkhiv [The Orthodox Belief of the Only, Holy, Catholic and Apostolic Church: Message of the Eastern Patriarchs], foreword by Metropolitan Hilarion (Ukr. Prav. Bratstvo im. Mytr. Vasylia Lypkivskoho, ZDA, 1966), 44. Pavel Evdokimov, Pravoslavie [Orthodoxy] (Moscow: Bybleisko-bohoslovskii institut sv. ap. Andreia, 2002), 372. 
This includes the Eucharist, a part of which is recognized as the words "Take and eat; this is My Body," "Drink ye all of this, this is My Blood." ${ }^{27}$ Similarly, the absolution formula in the sacrament of penance ("Odpuszcza tobie synu [...] Pan Chrystus niewidomie y ia" — "May our invisible Lord Jesus Christ absolve you, my son, and so do I") ${ }^{28}$ is not characteristic of the Byzantine tradition. ${ }^{29}$ And the sacrament function, according to the contemporary Latin tradition, is referred to as "anointing of the sick." 30

The soteriologic aspect of the treatise is determined by criticism of Calvin's teaching of predestination, according to which God has supposedly predefined some people to good and salvation and others to evil and death. In Cyril Lucaris's Confession of Faith, a fatalistic approach can be traced in Chapter 14: "We believe that free will is dead in the unregenerate, because they can do no good thing, and whatsoever they do is sin; but in the regenerate by the grace of the Holy Spirit the will is excited and indeed works but not without the assistance of grace." 31 Sylvester Kosov contradistinguishes the Orthodox approach, "że Bog wszechmogący swoia dobrocią, iako stworzył człowieka pierwszego, teraz prowadząc iego potomków w ten koniec, aby wszyscy byli zbawieni" ["that God Almighty with His kindness, as He created the first man, now conducts his descendants to such an end that all may be saved"]. ${ }^{32}$

Obviously, the author also touches on the mariological aspects of differences with reformatory theology, the worship of saints, the veneration of icons and holy relics, and belief in the Holy Tradition. Although it is actually about the incompatibility of Orthodoxy and Calvinist doctrine, a consistent dissociation from controversial statements is quite evident in Cyril Lucaris' Confession of Faith. After all, the author directly mentions shifting the accusations of Calvinism from Cyril of Constantinople to the entire Orthodox community: "Patriarcha [...] wasz konstantynopolski iest Kalwin, a wy go słuchacie; ergo, iesteście kalwini” ["Your Patriarch of Constantinople is [...] Calvin, and you listen to him, thence you are Calvinists"]. ${ }^{33}$ Refuting these allegations, Sylvester Kosov refers to a delegation of Lviv burghers who, returning from Constantinople, talk about Cyril Lucaris' emotional disassociation from the alleged publication. The Patriarch proposed to anathematize him, as he shared Calvin's opinions. ${ }^{34}$

Much more succinct is Sylvester Kosov's critique of "The Polish Brothers" (derogatorily termed as "Arians"), Unitarian religious principles, in which they are associated with the ancient heretics convicted by the First Ecumenical Councils. Followers of Faust Socyn, numbering up

27 Kossow, "Exegesis," 428.

28 Kossow, "Exegesis," 429.

29 Ihor Isichenko, “Myr s Bogom cheloveku' v konteksti bohoslovia pokaiannia," ["Peace with God to Man in the Context of the Theology of Repentance,"] in Vybrani tvory: $u_{3} t$. by Inokentii Gizel (Lviv: Svichado, 2010), 145-48. Kossow, "Exegesis," 430. "Confession of Cyril Lucaris."

32 Kossow, "Exegesis," 437.

33 Kossow, "Exegesis," 443. 
to 15 o societies in the Polish-Lithuanian Commonwealth, ${ }^{35}$ were active in Volyn and Podillia. ${ }^{36}$ In the Polish-Lithuanian Commonwealth, the Socinian intellectual and spiritual centre was the Racovian Academy that was founded in 1602 and numbered more than 1,000 disciples. ${ }^{37}$

In the Arian doctrine, the polemicist chooses two objects for criticism: the denial of divine filiations of Jesus Christ, and the denial of faith in the life of the human soul after the death of the body. In the former case, he clearly and distinctly outlines the Orthodox confession of Jesus Christ as one of the three persons of the Trinity, the Son of God begotten before time. In the latter case, a posthumous destiny of righteous souls and sinners is interpreted widely, with reference to Justin the Philosopher's judgment of distinguishing the righteous and the sinners and directing them to Heaven or Hell. At the same time, the intangible nature of the skies as a place for the righteous to stay in is reserved, with references to Thomas Aquinas and St. Augustine.

Sylvester Kosov very wittily and tactfully omits one of the key and most sensitive issues of the Orthodox-Catholic controversy of the late 16th - early 17th century, the problem of purgatory (locus purgatorij), referring to the authority of Robert Bellarmine: "sit purgatorium? De qoa quaestione nil Ecclesia defeniut; sunt autem multa opiniones." 38 Therefore, the alleged inconsistency of thought seems to remove this problem.

Blaming the Orthodox community of the Polish-Lithuanian Commonwealth for close contact with the Socinians was far from groundless. Everyone knew about Prince Constantine of Ostroh's close relationship with supporters of Faust Socyn's doctrine. In his treatise The Union of Greeks with the Church of Rome (1595), Ipatii Potii indignantly writes: "Some say they would rather go to the Arians, newly baptised, rather than to be under Papal authority and deal with the Papists! O my God! Is it not evident human blindness? Brothers begotten by one mother, the Universal Church, run fleeing to the stepmother's children! No wonder then that they revolt against us, following the heterodoxy and heretics!" 39 Many Unitarian congregations acted in Volyn and Kholmshchyna, and reputable schools of this confession operated in Kyselyn and Hoshcha. ${ }^{40}$ In 1630-1640 Iuri Nemyrych widely launched activities to spread Socinian communities. ${ }^{41}$

The defeat of "The Polish Brothers" community in Lublin in 1627 became the impetus for repressive actions in Volyn. ${ }^{42}$ In 1638 the Racovian Academy was closed, and the 1644

Orest Levytskyi, "Sotsinianstvo v Polshe i Iugo-Zapadnoi Rusi," ["Socinianism in Poland and South-

West of Russia,"] Kievskaia starina 4 (1882): 49.

"Protestantyzm v Ukraini," ["Protestantism in Ukraine,"] in vol. 5 of Istoriia relihii v Ukraini: u 10 t., ed.

P. Iarotskyi, P. Kraliuk et al. (Kyiv: Svit znan, 2002), 52-94.

37

Levytskyi, "Sotsinianstvo," 48.

38 Kossow, “Exegesis," 426.

39 Ipatii Potii, "Uniia hrekiv z kostiolom rymskym 1595 r.," ["Union of Greeks and Roman Church in 1595,"] in vol. 2 of Ukrainski humanisty epokhy Vidrodzhennia: Antolohiia (Kyiv: Naukova dumka, 1995), 103. Levytskyi, "Sotsinianstvo," 195-211.

41 Levytskyi, "Sotsinianstvo," 403-11.

Levytskyi, "Sotsinianstvo," 212-19. 
Tribunal Decree of Chaplychiv ordered elimination of all Socinian schools and prayer houses in the tenure. In 1638, with the town's transfer to Regina Solomyretska's ownership, the school of Hoshcha conceded to the Orthodox school at the newly founded St. Michael's Monastery. Finally, Cossack wars put an end to the existence of the Socinian communities on the occupied territories, and in 1658 the Sejm Constitution declared belonging to "The Polish Brothers" a state crime and offered a choice between emigration and conversion to the Catholic faith. 1oth July 166o was announced the last day of their belonging to the Polish-Lithuanian Commonwealth.43

The theological separation from Lutheranism was much less important to the author, given the small spread of this denomination in the Ukrainian and Belarusian territories. ${ }^{44}$ Yet it was Martin Luther who was perceived to be the founder and leader of the Reformation, and it was his religious doctrine that influenced the public consciousness of the Polish-Lithuanian Commonwealth through numerous and influential German colonies, as well as the presence of numerous Lutheran authors' works in the informational sphere of Europe.

The interpretation of these works by opponents provided the basis for Sylvester Kosov singling out three sensitive aspects of Lutheranism: 1) christological, associated with the broadening of the human nature of Jesus Christ to a ubiquitous presence in the Second Person of the Trinity - "y w niebie, z na ziemi, y w piekle, y w każdey na swiecie rżeczy" ["and in heaven, and on earth, and in hell, and in everything on earth"] ${ }^{45}$; 2) sacramental, which makes the baptism of infants dependent on their own faith ("propriam fidem actualem") 46; and 3) liturgical, according to which the presence of Christ in Eucharistic sacraments only reflects God's presence and is not the result of the consecration of bread and wine. Each of these aspects is intended to differentiate and oppose Lutheran and Orthodox theological concepts.

Thus, in all three cases, when talking about the leading Protestant confessions present in the mass consciousness of the residents of the Polish-Lithuanian Commonwealth - Unitarianism (nontrinitarianism, "The Polish Brothers," Socinianism), Calvinism, Lutheranism — Sylvester Kosov is guided by the aim to prove the incompatibility of a respective doctrine and Orthodox theological doctrine. This allows to refute the disseminated in polemical texts accusations (not always groundless!) of Ukrainian Orthodox theologians being under the influence of Protestant publications. At the same time, a radical distancing occurs from religious communities who had been the allies of the Polish-Lithuanian Commonwealth's Orthodox community in confronting the oppression of the state and the dominant denomination several decades earlier.

\section{The Religious Identity Manifestation}

Natalia Iakovenko indicates that "Confessionalisation, i.e. the gradual introduction of systematic Church control over the laity" 47 was typical during the first half of the 17 th century. It is worth

\footnotetext{
43 Levytskyi, "Sotsinianstvo," 423-25.

44 "Protestantyzm v Ukraini," 20-24.

45 Kossow, “Exegesis,” 442.

46 Kossow, "Exegesis," 442.

47 Natalia Iakovenko, Narys istorii seredniovichnoi ta ranniomodernoi Ukrainy [An Outline of the History of Medieval and Early Modern Ukraine] (Kyiv: Krytyka, 2005), 302.
} 
pointing out that both the processes observed by Natalia Iakovenko and the CounterReformation phenomenon, which match in time, could be interpreted as "different aspects of the renewal in the Catholic Church in the 16th century." 48 The large-scale renewal of the Catholic Church, the program of which was developed and approved by the Council of Trent, was also stimulated by the polemics with Protestant doctrines. But the polemics themselves only became an impulse for the comprehensive disclosure and manifestation of the Church's own ecclesiological identity on the doctrinal level, as well as in preaching, liturgical practice, and the educational service. ${ }^{49}$

Corresponding processes also escalated in Kyiv in Petro Mohyla's times. The covert confrontation between the Brotherhood and the Kyiv Cave Monastery schools during the years 1631-1632, the combative opposition to the innovative trends in the Kyiv Cave School, and the breakthrough of new pedagogical trends consonant with the Ratio Studiorum ${ }^{50}$ — such was the local context when the Exegesis appeared. And Sylvester Kosov, the prefect of the Kyiv Cave School (1631-1632), who became the first prefect of the Kyiv-Mohyla Collegium (1632-1635), ${ }^{51}$ was an active participant, organizer, and spokesperson of these processes.

Despite of the tradition of the polemic texts, Sylvester Kosov in his writing does not accuse the dominant denomination of oppression, nor the royalty - of discrimination. On the contrary, he gratefully speaks of King Sigmund III (Sigismund III Vasa, also known as Sigismund III of Poland, Polish: Zygmunt III Waza, Lithuanian: Žygimantas Vaza) and King Vladislaus IV (Władysław IV Waza) as patrons of Orthodox schools. The author does not criticise the Catholic Church and its theology. Likewise, there is no appeal to Church history: neither the conventional consideration of the conflicts between the Old and New Rome, nor the revision of the chronicles of the Kyiv metropolitans with emphasis on the traditional relations between the Ukrainian Cathedra and Constantinople. Instead, the author extensively uses Biblical and patristic texts, as well as (not so often) liturgical hymns and canonical documents in order to justify his theses.

The reasons why the author's main argument is reference to the Holy Scriptures are quite understandable. They are consistent with the long tradition of Christian literature, according to which in the Middle Ages an appropriately interpreted citation of the Bible was considered unshakable testimony of the truthfulness of the author's statements. Appealing to the Bible was the only convincing tool in the polemics with Protestant authors adhering to the Reformation principle of Sola Scriptura, the belief that the Holy Scripture was the unique source of God's

48 A. Apollonov and A. Gorelov, "Kontrreformatsyia," ["Counter-Reformation,"] in vol. 2 of Katolicheskaia entsyklopedyia (Moscow: Izd-vo Frantsiskantsev, 2005), 1263.

49 Joseph Lortz, vol. 2 of Istoriia Tserkvi, rassmotrennaia v sviazi s istoriei idei [A History of the Church Viewed through the History of Ideas] (Moscow: Khristianskaia Rossiia, 2000), 140-212.

$5^{\circ}$ R. Paranko and A. Masliukh, trans., Ratio Studiorum / Uklad studii Tovarystva Isusovoho. Systema iezuitskoi osvity [The Statute of Studies of the Society of Jesus: The Jesuit Education System] (Lviv: Svichado, 2008), 21-24.

$5^{1} \quad$ Kyievo-Mohylianska akademiia v imenakh:XVII-XVIII st. Entsyklopedychne vydannia [Kyiv-Mohyla Academy in the Names, 17th-18th Centuries: Encyclopaedias] (Kyiv: Vyd. dim "KM Akademiia," 2001), 286. 
Revelation. And a special decree of the Council of Trent recognized the books of the Old and New Testaments - along with the Holy Tradition! - as the "source of all kinds of redemptive truth and science, $[. .$.$] because God is the sole author of both of them." { }^{52}$

The epigraph to the work is taken from Psalm 119: "Deliver me from the oppression of man: so will I keep thy precepts" (Ps. 119:134). ${ }^{53}$ The author offers the Latin text: "Libera me a calumniis honinum, et custodiam mandata Tua" (p. 424), apparently, according to a formally approved translation of The Vulgate. This was an even earlier edition of The Vulgate, because already in The Clementine Vulgate of 1592 this very verse reads differently: "Redime me a calumniis hominum ut custodiam mandata tua." ${ }^{54}$

As usual in Baroque texts, the epigraph serves as a symbolic key to the book's code. Loyalty to God's commandments is equated with the loyalty of Ukrainian theologians, who the author defends against unfair accusations ("the oppression of people"), to the The Holy Scriptures and the apostolic tradition embodied in the sacramental life and wisdom of the Church Fathers.

The references to The Holy Scriptures are often made in the form of citations. In addition to the aforementioned cited epigraph, the text includes quotations from The Book of Kings (1 Kings 14:8), Prophet Micah (Micah 5:1), Psalms 5 (Ps. 5:5), 72 (Ps. 72:25), 94 (Ps. 94:8), 109 (Ps. 109:3), The Proverbs of Solomon (Proverbs 24:16), The Gospels of Matthew (Matthew 6:12; in the margins erroneously named Ioan. 6; 27:46; 9:15), Mark (Mark 13:32; 16:6); Luke (Luke 2:52; 6:41), John (John 2:3; 3:5; 6:24; 19:28), The Acts of the Apostles (Acts7:51; 13:48), Apostle Paul's Epistle to the Romans (Romans 2:6; 7:23), Corinthians (1 Corinthians 15:10; 2 Corinthians 5:15), Ephesians (Ephesians 4:9), Timothy (1 Timothy 2:4; 4:1; 2:5;), Colossians (Colossians 4:2); Thessalonians (2 Thessalonians 3:1), Hebrews (Hebrews 2:9), Apostle John' the Divine Epistle (1 John 2:2), Revelation of John the Divine (Revelation3:20).

The quoted text is always in Latin. This is the text of The Vulgate recognized by the Council of Trent as the only canonical translation permitted for church use. But, despite the fact that the Council subjected to anathema those who would not use "the old Latin edition of the Vulgate," 55 it had to recognize the variant readings in these editions and see to their elimination. Both in the biblical citations from the Exegesis and in the epigraph, there repeatedly occur minor discrepancies, as compared to The Clementine Vulgate of 1592. For example, the verse "Quid enim mihi est in cælo? et a te quid volui super terram?" (Ps. 73:25) "56 ["Whom have I in heaven but thee? and there is none upon earth that I desire beside thee."] reads as follows: "Quid mihi est in coelo, et a te quid volui super terram." ${ }^{57}$ Or the words of the Saviour to Nicodemus given by the Evangelist John: "Nisi quis renatus fuerit ex aqua, et Spiritu Sancto, non potest introire

Dokumenty Soborów, 210.

The English translations of the Biblical texts are cited according to The Holy Bible of King James version (London, 1611).

Biblia to jest Księgi Starego i Nowego Testamentu, z tacińskiego na język polski przetożone przez ks. d. Jakóba Wujka: Dosłowny przedruk z autentycznej edycji Krakowskiej z r. 1599 (Warszawa: Brytyjskie i zagraniczne Towarzystwo Biblijne, 1928), 928.

Dokumenty Soborów, 214. Biblia Sacra: Iuxta vulgatam versionem (Stuttgart: Deutsche Bibelgesellschaft, 1994), 861. Kossow, "Exegesis," 425. 
in regnum Dei" (John 3:5) ${ }^{58}$ has a slightly different wording: "Nisi quis renatus fuerit ex aqua \& Spiritu, non potest intrare in Regnum Dei." 59

In almost all cases, Sylvester Kosov adds a Polish translation to the Latin citations. A logical assumption would be that the Ukrainian author, respecting the canonical validity of sources, would use the translation of Father Jakub Wujek (1599) already authorized by the episcopate of the Polish-Lithuanian Commonwealth as an official Catholic translation. But one might consecutively observe significant differences between the author's translation and that of Jakub Wujek. For example, the epigraph cited above is translated as "Wybaw mię od potwarzy ludzkiey, abych strzegł przykazań Twoich" ["Save me from the proclivity of man so I can obey Your orders"], ${ }^{60}$ while in Jakub Wujek's version it is "Wykup mię od potwarzy ludzi: i będę strzegł mandatów twoich" ["Redeem me from the calumnies of men: that I may keep thy commandments"]. ${ }^{61}$ Another verse from Psalm 110, "From the womb of the morning: thou hast the dew of thy youth" (Ps. 110:3) appears as "z istności moiey przed wiekim cię urodził" ["you are begotten by my nature before all ages"], ${ }^{62}$ and in Wujek's version: "z żywota przed jutrzenką zrodziłem cię" ["Of life before the morning star I begot thee"]. ${ }^{63}$ And Apostle Paul's precept to Timothy about Christ's unique mediation mission ("For there is one God, and one mediator between God and men, the man Christ Jesus," 1 Timothy 2:5) Sylvester Kosov interprets as "Ieden Bog, ieden y posrzednik Boga y ludzi Cłowiek Chrystus Iezus" ["One God and one mediator between God and men is the man Jesus Christ"],64 almost the same as translated by Jakub Wujek: "Bo jeden Bóg, jeden i Pośrednik Boga i ludzi, człowiek Chrystus Jezus" ["For there is one God, and one mediator between God and men, the man Christ Jesus"]. ${ }^{65}$

Despite small differences, one should note the polemicist's indisputable recognition of the theological authority of Jakub Wujek's translation. An assumption that Sylvester Kosov could have used a different Polish version of the Holy Scriptures is not confirmed in comparisons with the earlier Catholic Bible Leopolity (by Jan Leopolita) (Scharfenberg, 1561), the Calvinist Brest (or Radziwill) Bible (1563), the Arian Nesvizh Bible (1570-1572), or the Calvinist and Lutheran Gdańsk Bible (1632).

The answer is deciphered by referring to the Ostroh Bible, the first complete edition of the Holy Scriptures in Church Slavonic, appearing in 1581 in Ostroh and adopted by the Kyiv Metropolis as a canonical source. The first verse (Ps. 119:134) is translated here as follows: "Izbavy mia ot klevety chelovicheskiia, i sokhraniu zapovidi tvoia" 66 — "Deliver me from the oppression of man: so will I keep thy precepts." The second (Ps. 109/110:3) is rendered "Iz chreva prezhde

58 Biblia Sacra, 1661.

59 Kossow, "Exegesis," 433.

6o Kossow, "Exegesis," 422.

$61 \quad$ Biblia to jest Księgi, 587 .

62 Kossow, "Exegesis," 424.

63 Biblia tojest Księgi, 58 o.

64 Kossow, "Exegesis," 435.

65 Biblia to jest Ksieggi, 231.

66 Ieromonakh Rafail (Roman Turkoniak), comp., Ostrozka Bibliia [Ostroh Bible] (Lviv: Ukrainske Bibliine Tovarystvo, 2006), 965 . 
dennytsa rodykh tia" ["from the womb of the morning: thou hast the dew of thy youth"]. ${ }^{67}$ Paul's words are rendered as follow: "Iedyn bo iest Boh, I iedyn Khodatai Bohu I chelovikom, chelovik Khrystos Iisus" ["For there is one God, and one mediator between God and men, the man Christ Jesus"]. ${ }^{68}$

Comparison of the three texts suggests that Sylvester Kosov, making use of both translations of the Holy Scriptures adopted by the Catholic Church of the Polish-Lithuanian Commonwealth at the beginning of the $17^{\text {th }}$ century as canonical, compares those translations with the Ostroh Bible and makes minor adjustments to the Polish version, providing for unanimity with its Orthodox canonical translation. This textual thoroughness, along with care for faithfulness to the patristic tradition and that of the Local Church, altogether fits into the post-Trent culture characteristics of using biblical texts, "following the example of the Orthodox Fathers, with the same reverence and respect." 69

In addition to the literal citation of the sacred text, in several cases there are more mediated forms of linking the author's statements with the biblical context. Thus, when describing the forms of the baptism sacrament, the author, without quoting the Latin translation of The Vulgate, directs the reader to Christ's words cited by John the Divine (John 3:5): "kto się nie odrodzi od wody [...]" ["except a man be born of water"].$^{70}$ The story about the anointment is accompanied with a reference to the same episode of the Saviours' conversation with Nicodemus (John. 3:5 and on), Christ's promise of baptism in the Holy Spirit (Acts 1:5), somehow associated with Apostle Paul, and the Lord's reply to the ambitious request of Zebedee's sons: "Can ye drink of the cup that I drink of? and be baptized with the baptism that I am baptized with?" (Mark 10:38)..$^{71}$ Writing about the sacrament of ordination, the author directs the reader to Paul's remark to Timothy (1 Timothy 4:14): "Niezaniedbyway łaski, ktora iest w tobie" ["Neglect not the gift that is in thee"]. ${ }^{72}$ He seeks sacramental sources of anointment in the words of the letter of Apostle James (James 5:14): "Chorzeie ktory z was, niech przywiedzie praesbytery cerkiewne, aby się modlili nad nim, pomazuiąc go oleiem w imię Pańskie" ["Is anyone sick among you? Let him call for the elders of the church; and let them pray over him, anointing him with oil in the name of the Lord"].73

The rebuttal of the Calvinist thesis of justification by faith refers to the faith of Judas Iscariot, which did not prevent his betrayal, as well as the faith mentioned in the Acts of the Apostles Simon the Sorcerer (Acts 8:9-24) and Nicholas of Antioch (Acts 6:5), whose name in the interpretation of post-Trent exegeses were associated with the heresy of Nicolaitans. ${ }^{74}$ The evidence of sagacity of the righteous is taken from the Prophets Samuel (1 Kings 19:18) and

67 Rafail, Ostrozka Bibliia, 957.

68 Rafail, Ostrozka Bibliia, 1870.

69 Dokumenty Soborów, 210.

$70 \quad$ Kossow, “Exegesis," 427.

$71 \quad$ Kossow, "Exegesis," 428.

72 Kossow, "Exegesis," 430.

73 Kossow, "Exegesis," 43 o.

74 Fritz Rinkler and Gerhard Maier, Bibleiskaia Entsiklopediia Brokhauza [Brockhaus Bible Encyclopedia] (Paderborn: Christliche Verlagsbuchhandlung, 1999), 633. 
Elisha (4 Kings 5:8-19), ${ }^{75}$ Old Testament sources of fasting are derived from the experience of King Saul and Jehoshaphat (1 Kings 14:24; 1 Paralipomenon 20:3), Ninevites, warned by Jonah the Prophet of impending punishment (Jonah 3:5-9), and Queen Esther (Esther 4:17 et seq.). Examples of confessions are found in John the Baptist (Matt. 3:6), as are mentions of early Christians converted by the apostles (Acts 19:18).

Perhaps most characteristic of the Baroque style is the use of biblical allusions in the final concept: "aby naszey Zuzannie dać raczył swe Daniele" ["may he deign to give our Susanna her own Daniel"], ${ }^{76}$ where the author wittily alludes to a character from a deuterocanonical chapter of the book of the Prophet Daniel, Susanna, who was rescued by Prophet Daniel from the lustful pursuit of corrupt judges (Dan. 13:1-64). ${ }^{77}$

It is obvious that the polemics with representatives of Protestant confessions made it unreasonable to refer to liturgical and patristic texts, because the denial of the role of the Holy Tradition as a source of God's revelation equal to the Holy Scriptures was one of the cornerstones of the Reformation. At the same time, Sylvester Kosov often willingly appeals to the sources which he considers decisive for preserving the continuity of the apostolic tradition and the identity of the traditional Church, both Eastern and Western. For instance, his argument in defence of righteous souls remaining in heaven is presented as church anthems ("gimny cerkiewne") ${ }^{78}$; the texts of the Liturgy of Saint Basil are evidence of the redemptive power of prayer for the departed, ${ }^{79}$ the words of John Chrysostom's liturgy affirm the belief in the wardship of the prayer to the Virgin and all the saints ${ }^{80}$ and in the veneration of icons, ${ }^{81}$ the content of the New Testament sacrifice is revealed by the words of anaphora of both liturgies. ${ }^{82}$ And the condemnation of heretical teachings is illustrated with the order of Sunday of Orthodoxy. ${ }^{83}$

Every now and then the author refers to the authority of the Church Fathers: when thinking about the theological nuances of ideas about life after death, ${ }^{84}$ when describing the Orthodox doctrine of the sacrament of baptism, ${ }^{85}$ the Eucharist, ${ }^{86}$ when the problem concerns the combination of the Godly and human nature in the figure of Jesus Christ, ${ }^{87}$ and when refuting

\footnotetext{
75 Kossow, “Exegesis," 438.

76 Kossow, “Exegesis," 447.

77 Ieromonakh Rafail (Roman Turkoniak), trans., Bibliia. Knyhy Sviatoho Pysma Staroho ta Novoho Zavitu

[The Bible. Books of the Holy Scriptures of the Old and New Testaments] (Kyiv: Ukrainske Bibliine

Tovarystvo, 2011), 837-39.

78 Kossow, “Exegesis," 425.

79 Kossow, "Exegesis," 429.

$80 \quad$ Kossow, "Exegesis," 438.

$81 \quad$ Kossow, "Exegesis," 439.

82 Kossow, "Exegesis," 440.

83 Kossow, "Exegesis," 426.

84 Kossow, "Exegesis," 425.

85 Kossow, "Exegesis," 427.

86 Kossow, "Exegesis," 428.

87 Kossow, "Exegesis," 436.
} 
the theory of the predestination of human destiny. ${ }^{88}$ He refers to the position of the Church Fathers ("oyców świętych") in the case of veneration and fasting, ${ }^{89}$ as well as when revealing the doctrine of consecration ("trans[s] ubstantiacyę") of bread and wine into the Body and Blood of Christ. ${ }^{90}$

Referring to the Fathers' spiritual experience as a whole, the author elaborates it in some idividuals that represent the wisdom of the Church. John Chrysostom's name appears in the text most frequently: eight times (along with the original version of the common name, Chryzostom. Zlatousty the slavonised version, appears once).${ }^{91}$ Saint Basil the Great and Hieromartyr Justin Philosopher are mentioned six times each. Sylvester Kosov refers to St. Augustine, St. John Damascene, and Ambrose (of Milan) three times each, and twice to Dionysios Areopagites. In addition, there are occasional references to Cyprian of Carthage, Blessed Theophylact, Cyril of Jerusalem, Athanasius of Alexandria, Gregory of Nyssa. Odd against the background of the Eastern Fathers of the Church but very symptomatic are references to the works of Thomas Aquinas and Cardinal Roberto Bellarmine, ${ }^{92}$ the leading representatives of Catholic theology of that time.

The epoch of the undivided Church is recalled in the doctrinal documents of the Sixth ${ }^{93}$ and Seventh ${ }^{94}$ Ecumenical Councils and the Local Council of Carthage, ${ }^{95}$ used as irrefutable argument of the general Church condemnation of the Armenian violation of traditions of the liturgical service (VI Council), denial of iconoclasm (VII Council), old traditions of priestly ordination (Carthaginian Council).

Such abundance of appeals to patristic sources proves that the work was addressed to the reader independent of the fostered by the Reformation critical attitude towards the Holy Tradition. And this did not necessarily have to be an Orthodox reader; in any case, he was supposedly open enough to early modern European theology, entirely concentrated in Latin universities. Because, not even considering the bold references to Thomas Aquinas of Bellarmine, even references to the Byzantine Fathers were made through printed publications of Latin translations of their works.

\section{From Script to the Cultural Sphere of Mohylanian Kyiv}

Obviously, the author of a Baroque text would use figurative expressions and characteristics to fill his discourse with the flavour of live language. This demeanour underlies the rhetorical program of the work and can be traced to the opening scene marked by ardent discussions and threats against the reformists of Kyiv schools. For, although it was claimed that "pioruny, [...]

\footnotetext{
88 Kossow, “Exegesis," 437-38.

89 Kossow, "Exegesis," 439.

90 Kossow, "Exegesis," 443.

91 Kossow, "Exegesis," 441.

92 Kossow, "Exegesis," 426.

93 Kossow, “Exegesis," 429.

94 Kossow, "Exegesis," 439.

95 Kossow, "Exegesis," 43 o.
} 
gromy y trzaskawice" ("lightning, [...] thunder, and thunderstorms"), which fell on Kyiv Caves School professors, "ięzyk atramentowy anatomizować nie może" ("could not be rendered in ink on paper", ${ }^{96}$ at the same time the author immediately lists a number of accusations and moulds the risk of death by means of the mentioned metonymy: feeding Kyiv Caves monastery school professors to Dnieper sturgeon. It would be opportune to draw attention to the integrity of the metaphoric pattern of the discursive ground: the author uses "atrament (ink) language," calling the opponent to battle on the "pole papierowe" ["the paper battlefield"].97

It is this virtual space that Sylvester Kosov projects onto the social and cultural landscape of Mohylanian Kyiv, where new schools "floryzują [...] palladyskie kunszty" ["cultivate Paladin abilities"], ${ }^{98}$ and thanks to which "muz uczciwych fontany oceanom się rozlewaią" ["fountains of benevolent Muses spill over the ocean"]. ${ }^{99}$ For him, the Latin language of education is the guarantee of the real equality of Ukrainian students in the Polish-Lithuanian Commonwealth where Latin dominates. "Poiedzie nieborak rusin na trybunał, na Sejm, na Sejmik, do grodu, do ziemstwa: bez łaciny płaci winy" ["the poor Rusyn will go to the tribunal, the Sejm, the local authorities, the city, the town hall: without Latin he will pay for his mistake"] ${ }^{100}$ For the author of the Exegesis exceeding the bounds of the cultural ghetto cherished by the conservative education system is not an escape from his own traditions but is its real discovery. "Udiamentowane" ("adorned with diamonds"): what an expressive epithet! With a comprehensive education, Rusyns will become devout priests and eloquent preachers who will successfully defend their rights in the courts and the Sejm.

The author need not face the problem of integrating into Europe: he naturally feels part of European civilization. The Latin language, the same as the philosophical heritage of antiquity or the reception of the Catholic patristic theology are also his, the Rusyn's, own acquisitions. His response to an opponent is sharp: "Każesz nam chleba żebrać, kiedy go mamy doma" ["You tell us to beg for bread when we have it at home"].101 The Orthodox theologian seamlessly adapts new ideas of Western theology, identifying the barriers with supporters of the new denominations through the experience of Catholic apologists. Thus Sylvester Kosov reveals himself to be a person of Reform, the Orthodox reform initiated in the Kyiv Metropolis, thanks to Petro Mohyla and in unison with the western Counter-Reformation. And the driving force of this Reform is to be the new Kyiv School created by Petro Mohyla and named after him.

\section{Bibliography}

Apollonov, A., and A.Gorelov. "Kontrreformatsyia." ["The Counter-Reformation."] In Katolycheskaia entsyklopedyia, 1263-65. Vol. 2. Moscow: Izd-vo Frantsiskantsev, 2005.

\footnotetext{
96 Kossow, “Exegesis," 423.

97 Kossow, "Exegesis," 443.

98 Kossow, "Exegesis," 422.

99 Kossow, "Exegesis," 446.

100 Kossow, "Exegesis," 444

101 Kossow, "Exegesis," 445.
} 
Bellarmin, Robert. Katechizm rzymski abo krotka nauka katolicka wszystkim chrześcianom do zbawienia naypotrzebniejsza. Wilno, $175^{2}$.

Biblia Sacra Vulgatae editionis Sixti V. jussu recognita atque edita. Venetiis: Apud Nicolaum Pezzana, 1754 .

Biblia Sacra: Iuxta vulgatam versionem. Stuttgart: Deutsche Bibelgesellschaft, 1994.

Biblia to jest Księgi Starego i Nowego Testamentu, z tacińskiego na język polski przetożone przez ks. d. Jakóba Wujka: Dosłowny przedruk z autentycznej edycji Krakowskiej z r. 1599. Warszawa: Brytyjskie i zagraniczne Towarzystwo Biblijne, 1928.

Dokumenty Soborów Powszechnych: Tekst taciński, polski. Vol. 4 (1511-1870). Kraków: WAM, 2005. Evdokimov, Pavel. Pravoslavie [Orthodoxy]. Moscow: Bybleisko-bohoslovskii institut sv. ap. Andreia, 2002.

Kossow, Sylwestr. "Exegesis, to iest danie sprawy o szkołach kiowskich y winnickich (1635)." Arkhiv Iugo-Zapadnoi Rossii 8.1 (1914): 422-47.

Gerych, Iurii. “Exegesis Sylvestra Kossova." [“Sylvester Kossov's Exegesis."] Yorkton, 1958.

Golubev, S. T. KievskiimitropolitPetrMohylai iego spodvizhniki(Opyt istoricheskogo issledovaniia): $v 2 t$. [Metropolitan of Kyiv Petro Mohyla and his Associates (Historical Research Experience), in 2 vols. ]. Vol. 1. Kyiv: Typ. H. T. Korchak-Novytskogo, 1883.

Iakovenko, Natalia. Narys istorii seredniovichnoi ta ranniomodernoi Ukrainy. [An Outline of the History of Medieval and Early Modern Ukraine]. Kyiv: Krytyka, 2005.

Isichenko, Ihor. "Myr s Bohom cheloviku' v konteksti bohoslovia pokaiannia." ["Man's Peace with God in the Context of the Theology of Repentance."] In Vybrani tvory: $u_{3} t$. by Inokentii Gizel, 133-51. Lviv: Svichado, 2010.

Isichenko, I. Kyievo-Pecherskyi pateryk u literaturnomu protsesi kintsia XVI — pochatku XVIII st. na Ukraini [The Kyiv Caves Patericon in the Literary Process of the Late 16th - Early 18th Centuries in Ukraine]. Kyiv: Naukova dumka, 1990.

Isichenko, Iu. "Pravoslavna kontrreformatsiia ta rozvytok barokkovoi kultury Ukrainy." ["The Orthodox Counter-Reformation and Development of the Baroque Culture of Ukraine."] In Druhyi Mizhnarodnyi konhres ukrainistiv (Lviv, 22-28 serpnia 1993 r.): Dopovidi i povidomlennia. Literaturoznavstvo, 53-57. Lviv, 1993.

Khyzhniak, Z. I. Kievo-Mohylianskaia akademiia [Kyiv-Mohyla Academy]. Kyiv: Vyshcha shkola, 1988.

Korzo, Margarita. Ukrainskaia i belorusskaia katekheticheskaia traditsiia kontsa XVI-XVIII vv.: Stanovlenie, evoliutsiia iproblemazaimstvovanii [The Ukrainian and Belarusian Catechetical Tradition of the End of the 16th-18th Centuries: Establishment, Evolution and the Problem of Borrowings]. Moscow: Kanon+, 2007.

Kraliuk, Petro. Meletii Smotrytskyi i ukrainske dukhovno-kulturne vidrodzhennia kintsia XVI — pochatku XVII st. [Meletiusz Smotrzyski and the Ukrainian Spiritual and Cultural Revival of the Late 16th-Early 17th Centuries]. Ostroh: Vyd-vo Natsionalnoho universtytetu "Ostrozka akademiia," 2007.

Krekoten, V. I., and M. M. Sulyma, comp. Ukrainska poeziia: Seredyna XVII st. [Ukrainian Poetry: Mid-17th Century]. Kyiv: Naukova dumka, 1992. 
Kyievo-Mohylianska akademiia $v$ imenakh: XVII-XVIII st. Entsyklopedychne vydannia [Kyiv-Mohyla Academy in Names, 17th-18th Centuries: Encyclopaedia]. Kyiv: Vyd. dim "KM Akademiia," 2001.

Larin, Iu. V. "Knyha o viri iedynoi' (1619 r.) v konteksti rannioi barokovoi polemichnoi literatury." ["The Book of the Only Faith (1619) in the Context of Early Baroque Polemical Literature."] $\mathrm{PhD}$ diss. 10.01.01, Kharkiv, 2013.

Levytskyi, Orest. "Sotsinianstvo v Polshe i Iugo-Zapadnoi Rusi." ["Socinianism in Poland and the South-West of Russia."] Kievskaia starina 4 (1882): 25-57; 5 (1882): 193-225; 6 (1882): 401-32.

Lortz, Joseph. Istoriia Tserkvi, rassmotrennaia $v$ sviazi s istoriei idei [A History of the Church Viewed through the History of Ideas]. Vol. 2. Moscow: Khristianskaia Rossiia, 2000.

MacCulloch, Diarmaid. A History of Christianity: The First Three Thousand Years. London: Penguin Books, 2010.

Mironowicz, Antoni. Sylwester Kossow - biskup biatoruski, metropilita kijowski. Białystok: Białoruskie Towarzystwo Historyczne, 1999.

Ohiienko, Ivan, trans. Bibliia abo knyhy Sviatoho Pysma Staroho i Novoho Zapovitu, iz movy davnioievreiskoi ta hretskoi na ukrainsku nanovo perekladena [The Bible, or Book of the Scriptures of the Old and New Testaments, Newly Translated from the Hebrew and Greek Languages into Ukrainian]. Kyiv: Ukrainske Bibliine Tovarystvo, 2006.

Paranko, R., and A. Masliukh, trans. Ratio Studiorum / Uklad studii Tovarystva Isusovoho. Systema iezuitskoi osvity [The Statute of Studies of the Society of Jesus. The Jesuit Education System]. Lviv: Svichado, 2008.

Plokhii, Serhii. Nalyvaikova vira: Kozatstvo ta relihiia v ranniomodernii Ukraini [Nalyvayko's Faith: Cossacks and Religion in Early Modern Ukraine]. Translated by Sofiia Hrachova. Kyiv: Krytyka, 2005.

Potii, Ipatii. "Uniia hrekiv z kostiolom rymskym 1595 r." ["The Union of the Greek and Roman Churches in 1595."] In Ukrainski humanisty epokhy Vidrodzhennia: Antolohiia, 101-30. Vol. 2. Kyiv: Naukova dumka, 1995.

Pravoslavna vira Iedynoi, Sviatoi, Sobornoi i Apostolskoi Tserkvy: Poslannia Skhidnikh Patriiarkhiv [The Orthodox Belief of the Only, Holy, Catholic and Apostolic Church:Message of the Eastern Patriarchs]. Foreword by Metropolitan Hilarion. Ukr. Prav. Bratstvo im. Mytr. Vasylia Lypkivskoho, ZDA, 1966.

"Protestantyzm v Ukraini." ["Protestantism in Ukraine."] In Istoriia relihii v Ukraini: u 10 t., edited by P. Iarotskyi, P. Kraliuk et. al. Vol. 5. Kyiv: Svit znan, 2002.

Rafail, Ieromonakh (Roman Turkoniak), comp. Ostrozka Bibliia [Ostroh Bible]. Lviv: Ukrainske Bibliine Tovarystvo, 2006.

Rafail, Ieromonakh (Roman Turkoniak), trans. Bibliia. Knyhy Sviatoho Pysma Staroho ta Novoho Zavitu [The Bible. Books of the Holy Scriptures of the Old and New Testaments]. Kyiv: Ukrainske Bibliine Tovarystvo, 2011.

Rinkler, Fritz, and Gerhard Maier. Bibleiskaia Entsiklopediia Brokhauza [Brockhaus Bible Encyclopaedia]. Vol. 8. Paderborn: Christliche Verlagsbuchhandlung, 1999.

Runciman, Steven. Velikaia Tserkov v plenenii: Istoriia Hrecheskoi tserkvi ot padeniia Konstantinopolia v 1453 g. do 1821 g. [The Great Church in Captivity: The History of the 
Greek Church from the Fall of Constantinople in 1453 to 1821]. Translated by L. A. Gerd. Saint Petersburg: Izd-vo Olega Abyshko, 2006.

Shevchenko, Vitalii. Pravoslavno-katolytska polemika ta problemy uniinostiv zhytti Rusy-Ukrainy doberesteiskoho periodu: Monohrafiia [Orthodox-Catholic Polemics and Problems of the Union in the Life of Rus-Ukraine of the Pre-Brest Period:A Monograph]. Kyiv: Presa Ukrainy, 2002.

Sinkevych, Nataliia. "Paterykon" Sylvestra Kosova: Pereklad ta doslidzhennia pamiatky [Sylvester Kosov's Paterykon: Translation and Research of the Document]. Kyiv: Oleh Filiuk Publ., 2014. Smotrzyski, Meletiusz. Apologia peregrinatiey do kraiow wschodnich. Lwów, 1628.

Solovii, Meletii, ChSVV. Meletii Smotrytskyi iak pysmennyk [Meletiusz Smotrzyskyi as a Writer]. Part 1. Rome; Toronto: Pp. Basiliani, 1977.

Tazbir, Janusz. “Tolerancja w dawnej Polsce.” In Chrześciaństwo w dialogu kultur na ziemiach Rzeczypospolitej, 53-61. Lublin: Wyd-wo KUL, 2003.

"The Confession of Cyril Lucaris (Eastern Orthodox, 1629)." In Christian Resource Institute. Accessed February 26, 2015. http://www.crivoice.org/creedcyril.html.

The Holy Bible... of the King James Version... published in the year 1611. Oxford; New York, 2010 (reprint).

Vlasovskyi, Ivan. Narys istorii Ukrainskoi Pravoslavnoi Tserkvy [An Outline of the History of the Ukrainian Orthodox Church]. Vol. 2. New York; Kyiv: Bound Brook, 199o.

Zhukovskyi, Arkadii. Petro Mohyla i pytannia iednosty Tserkov [Petro Mohyla and the Question of the Unity of Churches]. Kyiv: Mystetstvo, 1997.

\section{(2)}

Archbishop Ihor Isichenko was born January 28, 1956. Studied at the Philological Faculty of A. N. Gorkiy Kharkiv State University (today the V. N. Karazin Kharkiv National University, 19741979); on staff at the Department of History of Ukrainian Literature at this University since 1981. Candidate Degree Thesis: The Kyiv-Pechersk Patericon in the Historical and Literary Processes from the End of 16th to the 18th Century in Ukraine (1987), Doctoral Degree Thesis: The Ascetic Literature of Kyivan Rus (2009). Researches Ukrainian literature of the Baroque. On July 7, 1993 he was ordained as Bishop of the Ukrainian Autocephalous Orthodox Church of the Kharkiv and Poltava Eparchy. Since 1997, his title is that of Archbishop. Has taught at the National University of Kyiv-Mohyla Academy since 2006. 